\title{
Analisa Perancangan Sistem Pendukung Keputusan Penentuan Penerima Beasiswa Dengan Metode Analytical Hierarchy Process (Studi Kasus : STIKES Bhakti Husada Mulia)
}

\author{
Crismantoro Budisaputro \\ Sekolah Tinggi Ilmu Kesehatan Bhakti Husada Mulia \\ Program Studi D3 Rekam Medis dan Informasi Kesehatan \\ crismantoro@stikes-bhm.ac.id
}

\begin{abstract}
Abstrak
Pembagian beasiswa dilakukan oleh beberapa lembaga yang bertujuan untuk membantu seseorang yang kurang mampu namun memiliki prestasi. Sekolah Tinggi Ilmu Kesehatan Bhati Husada Mulia Madiun merupakan salah satu perguruan tinggi yang memberikan beasiswa kepada mahasiswa. Proses seleksi secara manual membutuhkan ketelitian dan waktu yang cukup lama, hal ini mengakibatkan lamanya proses pengambilan keputusan penerima beasiswa. Sistem Pendukung Keputusan (SPK) penentuan mahasiswa penerima beasiswa akan mengolah data kriteria penerima beasiswa dengan Metode Analytical Hierarchy Process (AHP). Hasil analisa dari metode AHP akan menentukan urutan kandidat yang bisa menerima beasiswa berdasarkan besarnya bobot kriteria. SPK penentuan mahasiswa penerima besiswa ini dibangun dengan perangkat lunak PHP dan database MySQL. Perancangan sistem menggunakan Object Oriented Design dengan UML tools.
\end{abstract}

Kata kunci : SPK penentuan penerima beasiswa, Metode AHP

\section{PENDAHULUAN}

Pembagian beasiswa dilakukan oleh beberapa lembaga yang bertujuan untuk membantu seseorang yang kurang mampu namun memiliki prestasi. Sekolah Tinggi Ilmu Kesehatan Bhakti Husada Mulia Madiun (STIKES BHM) merupakan salah satu perguruan tinggi yang memberikan beasiswa kepada mahasiswa.

STIKES BHM memiliki beberapa program beasiswa, diantaranya beasiswa yang diberikan oleh Direktorat Jenderal Pendidikan Tinggi (DIKTI) yaitu BBM (Bantuan Belajar Mahasiswa) dan Beasiswa PPA ( Peningkatan Prestasi Akademik) serta beasiswa prestasi yang diberikan oleh Yayasan Bhakti Husada Mulia.

Proses penyeleksian selama ini masih dilakukan secara manual. Persyaratan yang akan menjadi kriteria penilaian cukup banyak, diantaranya Nilai IPK, prestasi mahasiswa, penghasilan orang tua, semester dan usia. Waktu yang diberikan untuk proses pendaftaran dan seleksi sangat terbatas, sementara itu proses seleksi secara manual membutuhkan ketelitian dan waktu yang cukup lama, hal ini mengakibatkan lamanya proses pengambilan keputusan penerima beasiswa.

Oleh karena itu perlu adanya suatu sistem yang mendukung proses penentuan penerima beasiswa sehingga bisa mempersingkat waktu seleksi dan meningkatkan kualitas keputusan dalam menentukan mahasiswa penerima beasiswa.

Berdasarkan latar belakang masalah yang sudah diuraikan sebelumnya, maka perumusan masalah dari penelitian ini adalah Bagaimana merancang dan membangun Sistem Pendukung Keputusan penentuan penerima beasiswa dengan Metode Analytical Hierarchy Process pada Program Studi D3 Rekam Medis STIKES Bhakti Husada Madiun?

Tujuan dari penelitian ini adalah sebagai berikut:

1. Untuk mempercepat proses pengambilan keputusan penentuan penerima beasiswa.

2. Merancang dan membangun Sistem Pendukung Keputusan penentuan 
penerima beasiswa dengan metode Analytical Hierarchy Process (AHP).

\section{KAJIAN PUSTAKA}

Beasiswa merupakan penghasilan bagi yang menerima, karena beasiswa bisa diartikan menambah kemampuan ekonomis bagi penerimanya, berarti beasiswa merupakan penghasilan ( Pasal 4 ayat (1) UU PPh/2000).

Tujuan beasiswa adalah untuk membantu meringankan beban biaya pendidikan siswa atau mahasiswa yang mendapatkan (Santiary, 2012).

Beasiswa diberikan kepada mahasiswa sesuai dengan aturan-aturan dan kriteria yang telah ditentukan, maka tidak semua calon penerima beasiswa akan diterima (Wibowo, dkk, 2009).

Sistem Pendukung Keputusan atau Decision Support System (DSS) merupakan sebuah sistem untuk mendukung para pengambil keputusan manajerial dalam situasi keputusan semi terstruktur (Santiary, 2012).

SPK adalah sebuah sistem berbasis komputer yang adaptif, interaktif dan fleksibel yang secara khusus dikembangkan untuk mendukung solusi dari permasalahan manajemen yang tidak terstruktur untuk meningkatkan kualitas pengambilan keputusan (Khoirudin dalam Wibowo,dkk, 2009).

Pada dasarnya SPK dirancang untuk mendukung seluruh tahap pengambilan keputusan mulai dari mengidentifikasi masalah, memilih data yang relevan, menentukan pendekatan yang digunakan dalam proses pengambilan keputusan, sampai mengevaluasi pemilihan alternative (Magdalena, 2012).

Salah satu metode sistem pendukung keputusan yang multikriteria adalah Analytical Hierarchy Process (AHP). AHP ini cukup efektif dalam menyederhanakan dan mempercepat proses pengambilan keputusan dengan memecahkan persoalan tersebut ke dalam bagianbagiannya (Magdalena, 2012).

Analytical Hierarchy Process (AHP) yang dikembangkan oleh Thomas L Saaty berguna dalam membantu pengambil keputusan untuk mendapatkan keputusan terbaik dengan membandingkan faktor-faktor yang berupa kriteria, AHP memungkinkan pengambil keputusan untuk menghadapi faktor nyata dan faktor tidak nyata (Turban dalam Hasibuan dan Vitari, 2010).

UML merupakan bahasa untuk visualisasi, spesifikasi, konstruksi, serta dokumnetasi. UML sebagai suatu cara untuk mengkomunikasikan idenya kepada para pemrogram serta calon pengguna sistem/perangkat lunak. Dengan adanyan bahasa yang bersifat standar, komunikasi perancang dengan pemrogram (komunikasi antar anggota kelompok pengembang) serta calon pengguna diharapkan menjadi mulus. ( Nugroho dalam Hisyam Wahid Luthfi, Berliana Kusuma Riasti, 2012).

Unified Modelling Language (UML) adalah kumpulan notasi grafis yang didukung oleh sebuah meta-model tunggal, yang membantu dalam menjelaskan dan merancang sistem perangkat lunak, khususnya sistem perangkat lunak dibangun menggunakan gaya berorientasi objek (Fowler's, Martin dalam Andy, 2013).

\section{METODE PENELITIAN}

Tempat penelitian penulis di Sekolah Tinggi Ilmu Kesehatan Bhakti Husada Mulia Madiun, yang beralamat di JL. Taman Praja No. 25 Kota Madiun.

Metode pengumpulan data yang dilakukan melalui membaca dan mempelajari referensi - referensi berupa jurnal ilmiah, skripsi, dan buku. Fasilitas internet juga dipergunakan untuk media sebagai mencari data atau informasi yang dipublikasikan di dunia maya yang berkaitan dengan obyek penelitian.

Melakukan pengamatan langsung pada aktivitas pengolahan data mahasiswa yang mengajukan beasiswa di STIKES Bhakti Husada Mulia Madiun

Wawancara dengan ketua BAAK STIKES BHAKTI HUSADA MULIA MADIUN untuk mendapatkan gambaran terhadap sistem yang sedang berjalan saat ini. 
http://e-journal.unipma.ac.id/index.php/doubleclick

ANALISA DAN PERANCANGAN

Analisa Metode Analytical Hierarchy Process (AHP)

Kriteria-kriteria penerima

beasiswa yang mempengaruhi dalam pengambilan keputusan dikelompokkan dalam 4 kriteria yaitu IPK, prestasi mahasiswa, penghasilan orang tua dan semester. Masing-masing kriteria digambarkan dalam hirarki seperti berikut:

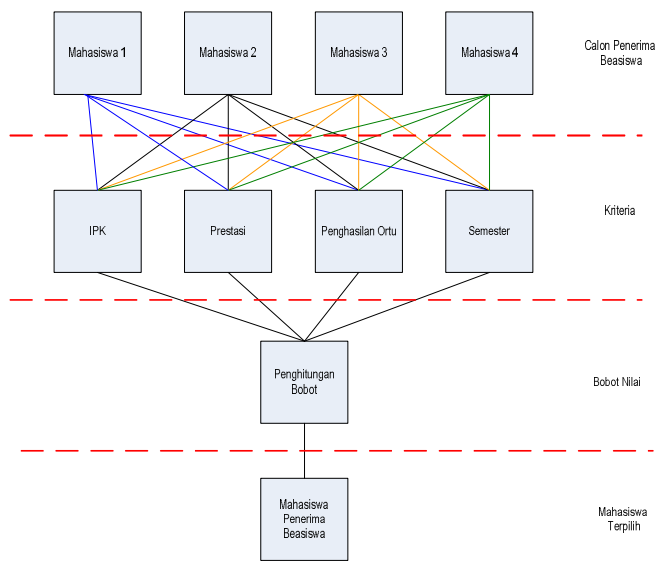

Gambar 1 Hirarki Kriteria Beasiswa

Setiap mahasiswa calon penerima beasiswa memiliki kriteria sesuai dengan ketentuan prasyarat penerima beasiswa. Setiap kriteria memiliki bobot nilai. Berdasarkan penghitungan bobot nilai tersebut maka dapat diambil keputusan siapa mahasiswa penerima beasiswa.

Pada penentuan bobot nilai kriteria, pertama ditentukan dulu parameter ukuran dari bobot nilai kriteria tersebut. Parameter ini yang akan dijadikan acuan untuk menentukan bobot nilai tiap-tiap kriteria.

Adapun parameter ukuran bobot adalah sebagai berikut:

Tabel 1 Parameter Ukuran Bobot Nilai

\begin{tabular}{lc}
\hline \multicolumn{1}{c}{ Parameter Ukuran } & Nilai \\
\hline Sangat Diutamakan & 5 \\
Diutamakan & 3 \\
Cukup Diutamakan & 2 \\
Kurang Diutamakan & 1 \\
\hline
\end{tabular}

Setelah menentukan parameter ukuran bobot nilai, langkah selanjutnya adalah menentukan ukuran bobot nilai tiap-tiap kriteria. Berikut adalah tabel parameter ukuran tiap-tiap kriteria:
Tabel 2 Parameter Ukuran Kriteria IPK

\begin{tabular}{llc}
\multicolumn{1}{c}{ Nilai IPK } & \multicolumn{1}{c}{ Parameter } & Nilai \\
\hline$>3,50$ & Sangat Diutamakan & 5 \\
$3,50 \geq$ IPK $>3,00$ & Diutamakan & 3 \\
$3,00 \geq$ IPK $\geq 2,50$ & Cukup Diutamakan & 2 \\
IPK $<2,50$ & Kurang Diutamakan & 1 \\
\hline
\end{tabular}

Tabel 3 Parameter Ukuran Prestasi/ Keaktifan

\begin{tabular}{llc}
\hline \multicolumn{1}{c}{ Prestasi } & \multicolumn{1}{c}{ Parameter } & Nilai \\
\hline Tingkat Nasional & Sangat Diutamakan & 5 \\
Tingkat Propinsi & Diutamakan & 3 \\
Tingkat Kota & Cukup Diutamakan & 2 \\
Lokal Kampus & Kurang Diutamakan & 1 \\
\hline
\end{tabular}

Tabel 4 Parameter Ukuran Penghasilan

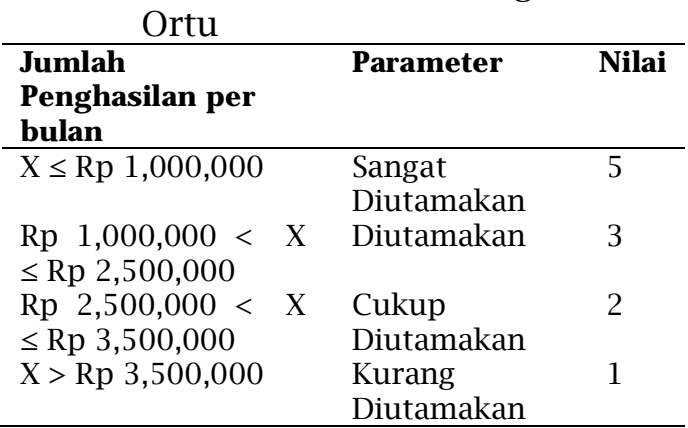

Tabel 5 Parameter Ukuran Semester

\begin{tabular}{cll}
\hline Semester & \multicolumn{1}{c}{ Parameter } & Nilai \\
\hline $7-8$ & Sangat Diutamakan & 5 \\
$5-6$ & Diutamakan & 3 \\
$4-3$ & Cukup Diutamakan & 2 \\
2 & Kurang Diutamakan & 1 \\
\hline \multicolumn{3}{c}{ Berdasarkan tabel parameter }
\end{tabular}
ukuran tiap kriteria yang sudah ditentukan diatas, maka ditentukan bobot nilai masing-masing kriteria sesuai dengan data mahasiswa. Matrik perhitungan bobot nilai adalah sebagai berikut:

Tabel 6 Data Mahasiswa Calon Penerima Beasiswa

\begin{tabular}{|c|c|c|c|c|c|}
\hline \multirow[t]{2}{*}{ No } & \multirow[t]{2}{*}{ Kriteria } & \multicolumn{4}{|c|}{ Calon Penerima Beasiswa } \\
\hline & & Mhs A & Mhs B & Mhs C & Mhs D \\
\hline 1 & IPK & 3,10 & 2,75 & 3,52 & 2,30 \\
\hline 2 & $\begin{array}{l}\text { Prestasi/ } \\
\text { Aktif }\end{array}$ & $\begin{array}{l}\text { Lokal } \\
\text { Kampus }\end{array}$ & Propinsi & Kota & Nasional \\
\hline 3 & $\begin{array}{l}\text { Penghasil } \\
\text { an Ortu }\end{array}$ & 2,1 juta & 1 juta & $\begin{array}{l}600 \\
\text { ribu }\end{array}$ & 4 juta \\
\hline 4 & Semester & 2 & 4 & 7 & 6 \\
\hline
\end{tabular}

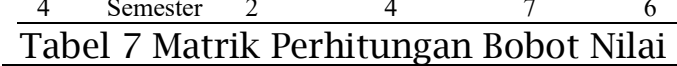

\begin{tabular}{llllll}
\hline \multirow{2}{*}{ Ko } & Kriteria & \multicolumn{4}{c}{ Calon Penerima Beasiswa } \\
\cline { 3 - 6 } & & Mhs & Mhs & Mhs & Mhs \\
& & 3 & 2 & 5 & 1 \\
1 & IPK & B & C & D \\
2 & Prestasi/Aktif & 1 & 3 & 2 & 5 \\
3 & Penghasilan & 3 & 5 & 5 & 1 \\
& Ortu & & & & \\
4 & Semester & 1 & 2 & 3 & 5 \\
Total Bobot Nilai & 8 & 12 & 15 & 12 \\
\hline
\end{tabular}


Berdasarkan data matrik perhitungan bobot nilai, maka dapat ditentukan mahasiswa penerima beasiswa sesuai dengan urutan prasyarat penerima beasiswa Langkah selanjutnya adalah melakukan perhitungan bobot nilai berdasarkan data-data mahasiswa. Proses penghitungan bobot nilai dapat digambarkan sebagai berikut:

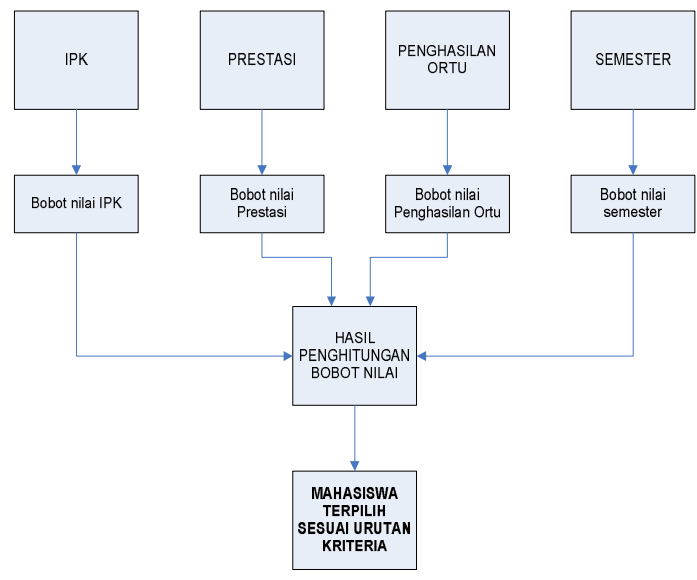

Gambar 2. Perhitungan Bobot Nilai

Use Case Diagram Sistem

Berikut ini adalah gambar use case diagram Sistem Pendukung Keputusan Penentuan Penerima Beasiswa pada STIKES BHAKTI HUSADA MULIA MADIUN. Pada diagram tersebut terdiri atas:

1. Aktor Staff BAAK, memiliki fungsionalitas:
a. Login
b. Mengelola Data Mahasiswa
c. Mengelola Data Jenis Beasiswa
d. Mengelola Data Kriteria
e. Mengelola Data Seleksi
f. Membuat Laporan Hasil Seleksi

2. Aktor Puket 1, memiliki fungsionalitas: Mengelola Data Hasil Seleksi

3. Aktor Mahasiswa, memiliki fungsionalitas: Melihat Data Penerima Beasiswa.

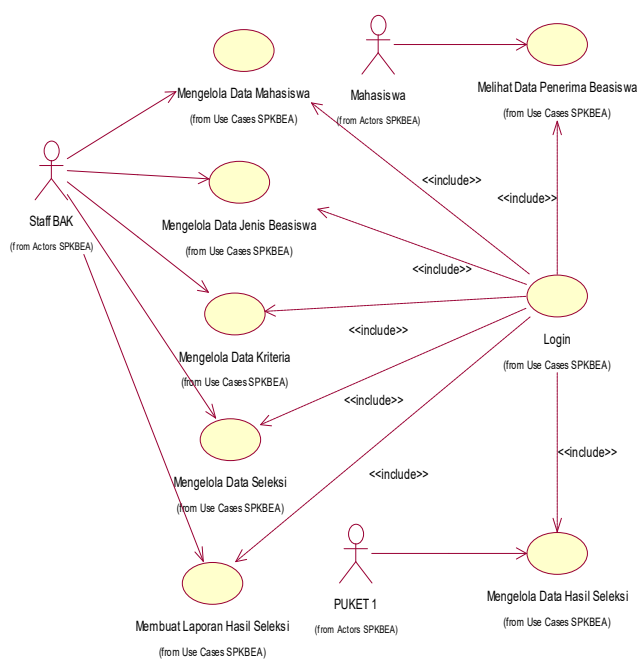

Gambar 3.Use Case Diagram SPK Beasiswa

\section{Class Diagram.}

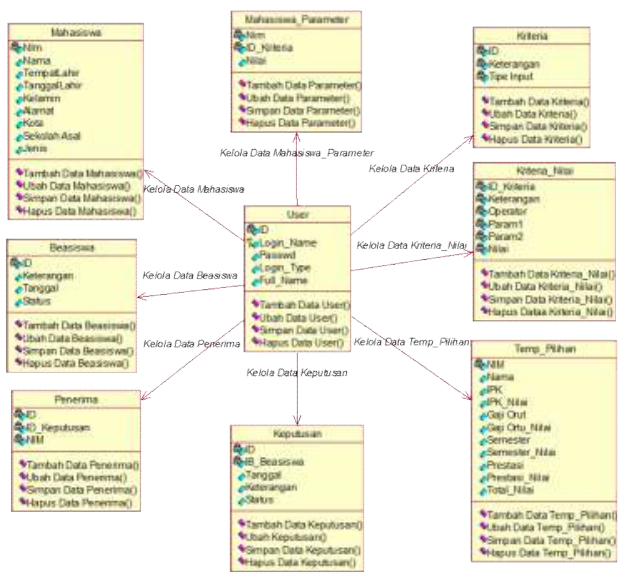

Gambar 4. Class Diagram SPK Beasiswa

\section{KESIMPULAN}

Sistem Pendukung Keputusan penentuan mahasiswa penerima beasiswa pada STIKES BHM telah berhasil dirancang. Berdasarkan hasil penelitian diatas maka dapat diambil kesimpulan sebagai berikut:

1. Hasil perhitungan bobot nilai menggunakan metode AHP diurutkan dari bobot nilai tertinggi ke bobot nilai terendah berdasarkan kriteria yang sudah ditentukan oleh Direktorat Jenderal Pendidikan Tinggi Kementerian Pendidikan Nasional.

2. Sistem yang akan dibangun hanya sebagai alat bantu untuk memberikan informasi data bagi staff BAAK dan 
WAKA 1 sebagai bahan pertimbangan mengambil keputusan

DAFTAR PUSTAKA

Andy Prasetyo Utomo, 2013, Analisa Dan Perancangan Sistem Informasi Parkir Di Universitas Muria Kudus, Jurnal Simetris Vol.3 No.1 (April 2013) ISSN : 2252-4983.

Hasibuan S.M. dan Vitari Aulia, 2010, Sistem Penunjang Keputusan Penerimaan Beasiswa

Menggunakan Metode Analytical Hierarchy Process(Studi Kasus Penerimaan Beasiswa Di SMAN 2 Metro), Konferensi Nasional Sistem dan Informatika 2010, KNS\&I10-025

Hisyam Wahid Luthfi dan Berliana Kusuma Riasti, 2012, Sistem Informasi Perawatan Dan Inventaris Perawatan Laboratorium Pada SMK Negeri 1 Rembang Berbasis Web, Indonesian journal on Computer Science-speed (IJCSS) 15 FTI UNSA VOL. 10 No.1 Februari 2012.
Magdalena Hilyah, 2012, Sistem Pendukung Keputusan Untuk Menentukan Mahasiswa Lulusan Terbaik Di Perguruan Tinggi (Studi Kasus STMIK Atma Luhur Pangkalpinang), Seminar Nasional Teknologi Informasi dan Komunikasi 2012 (SENTIKA 2012), ISSN: 20899815

Santiary Widyastuti A.P., 2012, Sistem Pendukung Keputusan Cerdas Dalam Penentuan Penerima Beasiswa, Jurnal Logic Vol.12 No.2.

Wibowo Henry, dkk, 2009, Sistem Pendukung Keputusan Untuk Menentukan Penerima Beasiswa Bank BRI Menggunakan Fmadm (Studi Kasus: Mahasiswa Fakultas Teknologi Industri Universitas Islam Indonesia), Seminar Nasional Aplikasi Teknologi Informasi 2009 (SNATI 2009), ISSN: 1907-5022. 